\title{
The problematics of reform and the 'Fijian' question
}

\author{
William Sutherland
}

\section{Introduction}

Following the coups of 1987 the indigenous Fijian-dominated state mapped out an economic reform program which by the early 1990s had lost much of its steam but regained momentum in the second half of the decade. This pattern was mirrored in political reforms. Three years after overthrow of the democratically-elected coalition government of the Fiji Labour Party (FLP) and the National Federation Party (NFP) came the racist and undemocratic constitution of 1990, which lay the foundation for the huge electoral victory in 1992 of the indigenous Fijian political party, the Soqosogo Vakavulewa ni Taukei (SVT). By the mid 1990s, however, the tide had begun to turn as internal struggles for democratic reform intensified. In 1995 the process of reviewing the 1990 Constitution began and in July 1997 the Constitution (Amendment) Act was passed. With that came fresh hopes for political stability and heightened expectations of economic growth but whether these hopes and expectations will be realised remains to be seen, even in light of the outcome of the 1999 general elections. In the twists and turns of Fiji's lost decade lie grounds for cautious optimism; on the other hand, while the democratic space is now much wider than before, as is evident in the huge victory of the FLP in the 1999 general elections, the key issue of indigenous Fijian discontent remains unresolved and therein lies a major threat to Fiji's future stability. 
The argument in this chapter is that from 1987 to about the mid 1990 s the reforms pursued by the post-coup state were driven primarily by the demands of nationalist indigenous Fijians. However, this project became increasingly problematic as the contradictions between the demands of economic reform on the one hand, and economic affirmative action in favour of indigenous Fijians on the other, intensified. From the mid 1990s the state increasingly moved away from its nationalist agenda and, driven now by stronger and more persistent external pressures for greater economic liberalisation, increased the pace and scope of economic reforms. In so doing, however, its capacity to deliver on the 'Fijian' question became even more limited; and the more it distanced itself from its nationalist agenda, the higher the level of indigenous Fijian disaffection became. By the second half of 1998, with the 'Fijian' question still unresolved, indigenous Fijian dissatisfaction with the SVT-dominated state had grown and a range of new indigenous Fijian political parties had emerged, which jockeyed amongst themselves for electoral advantage. In the aftermath of the 1999 general elections, the viability of the new FLP-led government will depend to a very large extent on how it manages the 'Fijian' question, and its performance in that regard will shape the country's prospects for growth and stability.

\section{The 'Fijian' question}

At the heart of the 'Fijian' question is a longstanding indigenous Fijian concern about their 'economic backwardness'. As early as 1959 an inquiry into the 'economic problems and prospects facing the indigenous Fijian people' identified the root causes as the indigenous Fijian communal way of life and the system of 'Fijian Administration' instituted by the colonial state. One year later another report concurred and indigenous Fijian economic disadvantage came to be explained in terms of their 'subsistence affluence', their preference for a 'leisurely' village lifestyle, a lack of entrepreneurship and capitalist discipline, communalistic as opposed to individualistic values, and a strong sense of traditional obligation (Sutherland 1992:112-13).

Educational underachievement was later added to the list, as was also a lack of capital.

The other key dimension of the Fijian question is the highly sensitive matter of native land leases, most of which are held by IndoFijians, especially sugarcane farmers (Prasad and Kumar, this 
volume). The origins of the problem here lie in the shift from plantation to small holder production in the colonial sugar economy. Native land leases are regulated by the Agricultural Landlord and Tenant Act of 1976 (ALTA) and in 1976 the indigenous Fijiandominated Alliance government granted lease extensions of up to 30 years. This decision was strongly opposed by indigenous Fijian nationalists and was a key reason for the Alliance's electoral defeat in April 1977. Twenty-one years later the leases began to expire, the first 47 in 1997, and by 2005 more than 5000 will have expired. Many indigenous Fijian landowners want the land back and leaseholders, understandably, are anxious. Up to 1998 , attempts to come up with an arrangement which broadly satisfied the stakeholders had failed and the ruling SVT, clearly with an eye to the upcoming elections, effectively put the matter on hold by referring the whole matter to a parliamentary committee. For the new government, there are rocky times ahead. But it is not only the land issue that remains unresolved.

At independence in 1970 indigenous Fijian hopes for improvement were pinned on the Alliance government but its early failure to fulfil these hopes led in 1973 to a stinging attack by Sakeasi Butadroka, an indigenous Fijian and Assistant Minister for Commerce and Industry. Soon afterwards Butadroka formed the Fijian Nationalist Party, which became the political spearhead of indigenous Fijian nationalist aspirations. The Alliance response was its policy of economic affirmative action, which had three key elements: preferential access for indigenous Fijians to state-funded scholarships; state-funded soft loans to assist indigenous Fijians in business; and state assistance to various indigenous Fijian business ventures. These initiatives had only limited success (Sutherland 1992:142-51; Ratuva, this volume). The 1987 coups renewed indigenous Fijian hopes that their fortunes might finally change.

In the area of education, a key response of the post-coup state was to increase funding for indigenous Fijian scholarships. In addition to the existing policy of reserving 50 per cent of Public Service Commission scholarships for indigenous Fijians, the annual allocation to a special education fund administered by the Fijian Affairs Board was increased from $\mathrm{F} \$ 3.5$ million to $\mathrm{F} \$ 4.5$ million. While this helped a larger number of indigenous Fijians, it did little to improve the poor and longstanding record of indigenous Fijian educational achievement. At the time of the coups indigenous Fijians were still performing poorly compared to the other ethnic communities; by 1995 the situation had not changed (Sharma 1997). 
Against this history of comparative underachievement in education, indigenous Fijian underrepresentation in the professional classes is not surprising. Figures from the 1986 census reveal, for example, that indigenous Fijians held 39 per cent of lower level professional and managerial jobs, 35 per cent of middle level ones, and only 17 per cent at the senior level (Sutherland 1992:153). The increased 'Fijianisation' of the public sector that followed in the wake of the coups is therefore not surprising. In May 1987, indigenous Fijians held 47.6 per cent of public service positions; Indo-Fijians held 47.8 per cent. Two months later, the figures were 53 per cent and 43 per cent respectively (Leckie 1991:67). By then, increasing numbers of Indo-Fijians, especially professionals, were emigrating-with the result that even more public service opportunities were created for indigenous Fijians. In 1991, for example, indigenous Fijians accounted for 61 per cent of public service appointments and 57 per cent of promotions. Five years later the figures were still high, at 58 per cent and 53 per cent respectively. Also, in 1996 indigenous Fijians accounted for only 23 per cent of public service resignations, while Indo-Fijians accounted for 70 per cent (Kumar 1997:87).

Successful 'Fijianisation' of the public service was not matched in the private sector. Seventeen years of indigenous Fijian state power under successive Alliance governments had failed to produce a successful indigenous Fijian capitalist class and the much better record of Indo-Fijians strengthened the widely-held but false view that IndoFijians dominated the economy, a perception that fuelled anti-IndoFijian sentiment. The coups were supposedly meant to change this and the state, now commanding much greater political control than previous Alliance governments, appeared much better placed to deliver on the promise of ensuring the 'paramountcy of indigenous Fijian interests' (Durutalo 1986). For the challenging task of increasing indigenous Fijian economic power, the state mapped out an ambitious plan which dovetailed with the goal of the Viti Chamber of Commerce, an indigenous Fijian organisation formed in late 1987, to 'promote and encourage meaningful participation by indigenous Fijians in business' (Sutherland 1992:193).

A key element of the plan was to strengthen the executive capability of the Fijian Affairs Board in order to enable it to formulate and implement specific policies and strategies. Another was the provision of a F\$20 million interest-free loan to the Fijian Affairs Board to buy shares in the Fijian Holdings Company Limited (FHC), which 
was 'the holding company for Fijians at the national level'. The FHC would in turn acquire shares in 'profitable companies in the industrial and commercial sectors' (Ratuva, this volume). The objective was for indigenous Fijians to own 15 per cent of the corporate sector by 1995 and not less than 30 per cent by the year 2000. Other initiatives included the reservation of certain lines of industrial and commercial activity for indigenous Fijians; a minimum level of indigenous Fijian ownership of at least one English daily newspaper; the introduction of an indigenous Fijian retail store scheme, later called the Eimcol scheme, to help 'selected indigenous Fijians with the necessary talent to successfully manage retail businesses'; and increased funding to the state-owned Fiji Development Bank (FDB) to allow greater preferential access for indigenous Fijians to soft loans for commercial purposes (Sutherland 1992:93).

Ten years after the coups, however, this grand design remained largely that; for the vast majority of indigenous Fijians it meant little. Certainly, the FHC grew, and there were marginally more indigenous Fijian businesses than before, including one indigenous Fijian-owned English daily newspaper. On the other hand, the Eimcol store scheme had collapsed and the number of public notices of receiverships and mortgagee sales underscored the continuing high level of indigenous Fijian business failure. To be sure, a small indigenous Fijian élite did well, as Ratuva discusses more fully in his contribution to this volume, but it can hardly be said that there was anything like a successful indigenous Fijian business class which remotely rivaled the dominance of established foreign and local, including Indo-Fijian, capital. Indigenous Fijian political power clearly had not translated into indigenous Fijian economic power. Much of the explanation for this lies in the contradictions between the post-coup state's nationalist agenda and its wider economic reforms.

\section{The contradictions of reform and the indigenous Fijian nationalist agenda}

Since independence in 1970 sugar and tourism have been the mainstay of the economy and the manufacturing sector remained relatively small until after the coups. At the center of the post-coup economic reforms, therefore, was the shift in industrial policy away from import-substitution towards export-promotion. Such a shift had been mooted as early as 1970 but it had 'an extremely long gestation period' 
(Akram-Lodhi 1996:263). Why was this so? Why was the Alliance government 'tentative' about shifting away from its importsubstitution strategy? The limited level of industrial development between 1970 and 1987, Akram-Lodhi correctly explains, was 'largely based on import substitution, and the economy was subject to a regulatory regime deploying quota, license, and tariff protection' (Akram-Lodhi 1996:263). The telling point about this regime, however, is that the major beneficiaries were a few local Indo-Fijian businessmen who, importantly, had close links with the Alliance government and who were financial backers of the Alliance party. With this kind of support, therefore, the Alliance's longstanding reluctance to change its industrial policy is not surprising. From the early 1980s, however, there was external pressure to effect such a shift.

A employment mission undertaken by the Institute of Development Studies of the University of Sussex in the United Kingdom argued in 1982 that Fiji's labour costs were uncompetitive by international standards and had to be reduced to enhance the country's export potential. In 1986 the World Bank did the same (Akram-Lodhi 1996:265). By then the Alliance government had sought to cut labour costs by announcing retrenchments in the public service as well as a freeze on all wages, salaries and increments (Sutherland 1992:173-74). What followed was widespread opposition, the birth of the FLP and, in April 1987, the Alliance's second electoral defeat. The coups that followed created the political space that made a decisive shift towards export-oriented industrialisation possible. To be sure, the shift was also a response to international trends towards economic liberalisation and export-oriented industrialisation, as well as specific advice from consultants and international agencies (Akram-Lodhi 1996:265). Without the coups, however, it is unlikely that the shift would have been as swift and wide-ranging as it was. But the change brought its own tensions. Having promised to deliver on indigenous Fijian economic aspirations, the post-coup state was now faced with the task of managing the inherent contradictions between the imperatives of economic liberalisation on the one hand and the demands of economic affirmative action on the other (Sepehri and Akram-Lodhi, this volume).

The showpiece of the post-coup economic reform agenda was the spectacular growth of the manufacturing sector and central to this success was the establishment of tax-free factories, most especially for 
garment production. Underpinning this shift towards export-oriented industrialisation was the policy of deregulation and the provision of highly attractive tax and other concessions. International competitiveness, however, required more than this, and in 1991 the push for labour market reforms began with the promulgation of draconian anti-labour legislation (Chand, this volume). In 1992 a value-added tax was introduced and plans for further tax reforms were flagged. Financial sector reforms were also planned, and so too key public sector reforms, including downsizing, performance-based remuneration, administrative reorganisation, and financial and budgeting reforms. In addition, state enterprises were earmarked for corporatisation or privatisation and a Public Enterprises Unit was established within the Ministry of Finance to oversee the process.

For the state these reforms were necessary to rescue the economy from the severe downturn that followed the coups and lay the foundation of longer-term economic growth. In terms of the task of delivering on indigenous Fijian economic aspirations, however, the reforms were problematic because they impacted negatively on large numbers of indigenous Fijians. Labour market reforms affected them as workers; the value-added tax did not discriminate between ethnic groups; the pain of public sector reforms increasingly fell on indigenous Fijians the more that the public service was 'Fijianised'; and divestiture of state assets hurt the many indigenous Fijians employed in state-owned enterprises. In the face of such negative impacts, the significant level of indigenous Fijian support for wider worker struggles-for example, against the value-added tax and the labour reforms-is not surprising. For the state this was a major concern, for the very political support on which it depended most critically was being eroded.

Worried by this the state began to waver in its commitment to implement economic reform and investors, of course, complained about a lack of leadership, prevarication and backpedalling. The state had hoped that with the reforms would come greater opportunities for indigenous Fijian economic advancement, especially in the burgeoning garment industry. Economic liberalisation, however, meant open competition and a 'level playing field', and economic affirmative action ran counter to this. Nowhere was the contradiction demonstrated more clearly than in the state's changing position on deregulation. 
Early in 1989 the regulation of imports was relaxed and the number of items subject to import licensing was reduced to 48 (Parliament of Fiji 1997a:63). Restrictions on the import of one of these items, white polished rice, was eased and of the 17,000 tons to be imported that year 3,000 tons were set aside for importation by indigenous Fijians (The Review, May 1995:28-29). Hari Punja, a leading Indo-Fijian importer and industrialist, whose business empire was then estimated at F\$180 million, cried foul (Sutherland 1992:194) but the state stood its ground and indigenous Fijians rushed for import licenses.

Significantly, FDB loans to indigenous Fijians for 'commercial/ business services' suddenly leapt, accounting for 43.5 per cent of the total value of all its commercial loans to indigenous Fijians. But this spurt of enthusiasm soon waned and, as Table 9.1 shows, the pattern of indigenous Fijian borrowing changed markedly. Borrowing for investment in real estate now became the preference and the value of FDB loans to indigenous Fijians for 'commercial/business services' fell to a mere 4.5 per cent in 1993, temporarily increased to 25.4 per cent in 1994 but then dropped back to a low of 3.7 per cent in 1995.

Indigenous Fijians soon realised that it was one thing to go into business, but quite another to be viable and successful. The harsh reality was that established competitors would not yield easily.

Table 9.1 Distribution of Fiji Development Bank commercial loans to indigenous Fijians by sector, 1989-96, per cent

\section{Service Sectors}

$\begin{array}{llllllll}1989 & 1990 & 1991 & 1992 & 1993 & 1994 & 1995 & 1996\end{array}$

Transport and
Communication
Real Estate
Wholesale/Retail
Commercial and
Business Services
Investment/Finance
Tourism

$\begin{array}{rrrrrrrr}30.4 & 25.8 & 37.7 & 21.8 & 34.1 & 16.4 & 9.2 & 4.6 \\ - & 31.5 & 36.2 & 25.8 & 22.6 & 36.7 & 61.6 & 58.1 \\ - & - & - & - & 14.8 & 11.3 & 7.6 & 2.8 \\ & & & & & & & \\ 43.5 & 28.9 & 13.4 & 17.6 & 4.5 & 25.4 & 3.7 & 31.5 \\ - & - & - & 10.9 & 16.3 & 2.9 & 7.5 & 1.8 \\ 10.0 & 1.0 & 0.7 & 3.4 & 1.9 & 3.7 & 3.2 & 0.5 \\ & & & & & & & \\ 7.7 & 3.6 & 8.0 & 15.6 & 1.5 & 1.9 & 3.6 & 0.5 \\ 0.4 & 2.4 & 1.7 & 0.6 & 0.5 & 0.8 & - & - \\ 8.0 & 6.8 & 2.3 & 4.3 & 3.8 & 1.7 & 3.6 & 0.2\end{array}$

Source: Fiji Development Bank 1992/93:8; 1994/95:13; 1995/96:19. 
Nevertheless, over this period indigenous Fijian nationalists complained increasingly that the government was not doing enough to help indigenous Fijians in business. They again pressed the point about Indo-Fijian economic power and reminded the government that deregulation undermined the policy of economic affirmative action. In the lead up to the 1995 National Economic Summit, the Subcommittee on Indigenous Fijian Participation in Business bemoaned, yet again, the lack of indigenous Fijian business success and argued that state support had to include softening the policy of deregulation.

The government's deregulation policy runs contrary to its policy of enhancing indigenous Fijian business participation because most Fijians are involved in small enterprises which are in their infancy and cannot compete in terms of economies of scale and product quality with more established (and mostly Indian) companies which developed during Fiji's import-substitution era. Therefore, Fijian entrepreneurs should be protected... Because of the need to replace market entry barriers for Fijians, they should get equal opportunities in government services that will be contracted out [as well as in] government entities and services to be privatised. Apart from a 50 per cent opportunity [for] Fijian business participation in the economy...tenders by Fijian suppliers should enjoy a 15 per cent preference margin (The Review, May 1995:28-29).

The Subcommittee had an ally in the Finance Minister, Berenado Vunibobo. Although widely perceived as a hardheaded economic rationalist, Vunibobo was also a nationalist and he was clear about where the major threat to the nationalist agenda lay. For him the business community 'essentially belong[ed] to the Indian community' and affirmative action was necessary.

The Fijians seem to have developed the feeling that by having political control, they are the master of the house. It doesn't work that way. You have to have a significant say in influencing the economy...but at the end of the day the Indian business community could squeeze the country dry if they choose to do so because of their hold on the economic levers. The Fijians realise that now. That is why there is so much input, so much concern, about helping and encouraging Fijians to get into the economic mainstream (The Review, May 1995:29).

With the Finance Minister taking this line it is not surprising that in the following year the value of FDB loans to indigenous Fijians for 'commercial/business services' increased markedly. From a mere 3.7 per cent of the total value of all commercial loans to indigenous Fijians in 1995 , it jumped to 31.5 per cent. On the other hand, the 
Subcommittee's plea for the state to go soft on deregulation and give indigenous Fijians more preferential treatment did not elicit a positive response. Here was evidence that the state was willing to go only so far, and further evidence that it was now distancing itself from the nationalist agenda would soon emerge.

Other, more influential sections of the private sector, especially several key Indo-Fijian companies, were also opposed to deregulation and in the following year the state's class bias towards them was revealed. In August Isimeli Bose, the Minister for Trade, Industry, Commerce and Public Utilities, announced a qualified softening of the deregulation policy. Competition would continue to be encouraged but there would also be limits. Certain interests, in his view, were much too important and had to be protected. Those interests, however, were not indigenous Fijian ones, as the following report on an interview with the Minister revealed:

He is keen on protecting the interests of local entrepreneurs-the Hari Punjas, the Vinod Patels and Mahendra Patels-and long established businesses such as Shell, Carlton Brewery and Morris Hedstrom. 'They have put their money where their mouth is'...Already the minister has advised the [Fiji Trade and Investment Board] to take special care of these local investors and make sure that they receive support...And he is going to 'fight very hard' to protect the big local investors. 'I will run to their help whenever they need me'. While the Minister is aware of the World Trade Organisation rules promoting a freer trading environment, Bose insists that at the end of the day, it's the national interest that 'must come first' (The Review, August 1995:38).

Bose's explicit privileging of the national interest, together with the conspicuous absence of indigenous Fijians from the list of local entrepreneurs whose interests were to be protected, underscored the state's increasing abandonment of its nationalist agenda.

Indo-Fijian entrepreneurs and 'long-established' foreign companies were the 'pillars of the economy' and it was they who would best advance the 'national interest'. They therefore required 'special care' and the state duly obliged. One month after Bose's announcement, 55.6 per cent of the businesses surveyed identified deregulation as the 'most critical' issue facing them (The Review, November 1996:58). Eight months later the figure was just 27 per cent (The Review, June 1997:21). The state had moved further away from the nationalist agenda and indigenous Fijian entrepreneurs, whose performance continued to be generally poor and showed little sign of improving, now had a minor 
place in the state's economic agenda. The prospect of this changing was further reduced in the following year, when indigenous Fijian economic performance and the whole policy of economic affirmative action were again publicly scrutinised. A well-known indigenous Fijian journalist brought to public attention yet again the continuing poor record of indigenous Fijians in business (Fiji Business Magazine, October 1996:20-21). Earlier, the policy of economic affirmative action had again been publicly questioned, this time by Don Aidney, a local Euro-Fijian and an influential economic figure of long standing (Fiji Business Magazine, July 1996:40-41).

By the end of 1996, then, with its nationalist agenda now giving way to a national one, the state began pursuing with renewed vigour the wider economic reform program mapped out in the immediate post-coup years but which had been frustrated by the requirements of its nationalist project. But this new resolve was not entirely of the state's own making. It was also a consequence of growing external pressures to adjust to the imperatives of globalisation.

\section{Global imperatives and the new reform agenda}

By the early 1990s global pressures for economic liberalisation had intensified. The Cold War was over, the Uruguay Round was nearing completion, and neoliberalism had swept the industrialised world and become even more firmly entrenched as orthodoxy in the International Monetary Fund, the World Bank, the Asian Development Bank, and other international organisations with which Fiji had close links. Increasing competition for shrinking aid budgets strengthened the hand of donors in pressing the case for economic reform, which the World Bank did in 19911993 and 1995 in three reports on the Pacific island economies, including Fiji (World Bank 1991; 1993; 1995b). The Bank also urged other donors to be more forthright in their policy advice to Pacific island governments (Sutherland 1998:5-6). Closer to home, Australia and New Zealand pushed for reform and the key regional site for intervention was the South Pacific Forum (referred to hereafter as the Forum). Wearing two hats-as Forum members and as major donors - they were uniquely well-placed to use the Forum to urge reforms on the island countries, and in the early 1990s the regional reform agenda which they were highly instrumental in developing began to emerge. 
In 1990 the Forum 'took cognisance of the rapid changes in the international political and economic situation' and in the following year 'endorsed the view that although many issues, such as programs of economic structural adjustment, required action at the national level, there was also a key role for regional action' (South Pacific Forum 1990; 1991). Such action was to begin in 1994 but in the meantime the general message about the need for adjustment and reform needed to be made more concrete. In 1992, therefore, Forum members agreed to put in place 'effective' domestic policies, give recognition to the vital role of the private sector, and develop a sound investment strategy (South Pacific Forum 1992). For Fiji, this was particularly significant. Investment was low and foreign investors, like many of their domestic, and especially Indo-Fijian, counterparts, were not enamoured of the government's policy of economic affirmative action.

In 1993 the Forum again reiterated the need for policy adequacy and private sector development (South Pacific Forum 1993) and in the following year Australia, as host of the Forum, put regional reform at the top of the agenda. Also at Australia's suggestion, the 1994 Forum established the Forum Finance Ministers' Meeting to begin the task of developing regional reform initiatives. The first meeting of the Forum Finance Ministers, which was funded by Australia, sought to 'improve overall economic management' and 'identified structural reform as a vital element in improving...competitiveness and efficiency' (Forum Finance Ministers, 21 February 1995). The second meeting agreed that member countries 'should not delay implementing necessary reforms until...forced to do so by economic crises or external pressures' (Forum Finance Ministers, 8 December, 1995).

The 1996 Forum noted the Ministers' 'progress towards defining a practical, regionally-focussed, economic reform agenda' and, to allow their agenda 'to cover the breadth of economic issues', agreed to expand membership of the ministers' meeting to include 'Forum Ministers with appropriate economic portfolios' (South Pacific Forum 1996). The meeting thus became known as the Forum Economic Ministers Meeting (FEMM) and met as such for the first time in Cairns in July 1997. There the ministers 'agreed that private sector development [was] central to ensuring sustained economic growth, and that governments should provide a policy environment to encourage this' (Forum Economic Ministers 1997). 
In an address to the Fiji Australia Business Council in the following month Australian Foreign Minister Alexander Downer warned against 'rely[ing] on inward policies of protectionism and import substitution to the exclusion of more outward-looking policies'. He noted the efforts of the FEMM in advancing the regional reform agenda and that Fiji, along with other Pacific island economies, was 'already well down the path of reforms', although he then added that the world was 'moving on quickly' and there was 'no room for a slackening of the pace of reform' (Downer 1997). One month earlier, at a joint conference of the New Zealand and Fiji Business Councils, Sir Roger Douglas, the architect of economic liberalisation in New Zealand in the 1980s, proposed a comprehensive package of reforms for Fiji which, he stressed, should be implemented in its entirety and not on a piecemeal basis. The conference gave its backing to Roger's package. In the audience was Fiji's indigenous Fijian Prime Minister, Sitiveni Rabuka (National Business Review, 20 June 1997). The key message from interventions such as these was clear: reforms were necessary and the momentum had to be maintained. For Fiji it was particularly apposite. Although there had been some progress, on the whole its record on reform was patchy.

By this time, Fiji had responded to other external pressures. The Mid-term Review of the Lomé Convention cast doubt over the future of Fiji's sugar exports and forced the government to draw up plans to restructure the industry. In relation to the manufacturing sector, continued pleas by Fiji to Australia to relax the rules of origin for preferential access of its manufactured goods, especially garments, under the South Pacific Regional Trade and Economic Cooperation Agreement (SPARTECA) met not only with refusal but strong urgings to become more competitive. Then, in April 1996, Fiji faced the World Trade Organization's (WTO) Trade Review Panel.

The Panel highlighted Fiji's relatively slow economic growth and raised questions about fiscal balance; progress on public enterprise reforms; the promotion of greater competition; exchange and price controls; and land tenure issues, including changes to the ALTA. Attention was drawn to 'the slowing pace of tariff reform and liberalisation'; Fiji was 'encouraged...to continue progress on this front and in relation to deregulation' and questions were posed about 'measures to encourage greater competitiveness in the clothing sector'. In relation to the service sector, the Panel sought further information 
on the 'scope and timing' of the 'new policy statement on services [being developed] by the Fijian Government'. A whole range of other issues was also brought to scrutiny. The Panel welcomed answers given by Fiji to questions and 'looked forward to written replies on outstanding issues' (World Trade Organization 1997:2-5).

In November 1996 the Finance Minister presented his budget for 1997. The title of his budget address is revealing: 'Confidence through clear policy'. That the Minister was concerned about the confidence of external actors, especially Australia, the European Union and the WTO, is suggested by this remark:

We would be very short-sighted to retreat from the policies of liberalisation...For too long we have relied solely on preferential trade agreements...[but] this is a dangerous strategy, as continued benefits from SPARTECA...and the Lomé Convention are beyond our control. As a step in the right direction and away from relying on [such] trade agreements, Fiji has...[joined] the World Trade Organization. WTO membership greatly assists Fiji's integration into the global economy. But it also places an obligation to comply with its requirements (Ministry of Finance and Economic Development 1996a:12).

The subtitle of the Minister's address, 'A commitment to Fiji's future', is also telling. The government's commitment was to Fiji's future, not indigenous Fijians' future. In his speech there was not a single mention of indigenous Fijian interests or of the policy of economic affirmative action, let alone any suggestion that these might be boosted. Economic affirmative action did not cease, of course, but clearly the government's agenda was now a national one. As the Minister put it, 'since 1987, a new economic strategy has been formulated and implemented. The new approach seeks to encourage the economy to grow for the benefit of all our people' (emphasis added) (Ministry of Finance and Economic Development 1996a:2). The nationalist agenda was weakening and in the face of growing external pressure the wider economic reform program gathered speed.

The record until then was uneven at best. There had been some deregulation but some backtracking as well: the anti-labour laws introduced in 1991 had been repealed; progress on public sector reform was minimal; only two state-owned enterprises had been corporatised, the Department of Post and Telecommunications and IKA Corporation; and only two had been partly privatised, the Fiji Pine Commission and the Marketing Authority (Ministry of Finance 
and Ministry of National Planning 1996b:54). But things were about to change and the Minister of Finance signaled the government's renewed resolve in November 1997 when he presented to the parliament the budget for the following year.

Six more govemment enterprises were earmarked for corporatisation. The telecommunications sector, which had recently been reviewed, would be opened up to competition. Further tax reform would be implemented following completion of two studies on company and income tax then underway and, in line with the recently announced Investment Policy Statement, the investment regime would be streamlined to make it more workable and transparent. The domestic capital market would be boosted by the creation of a Capital Market Development Authority. Foreign exchange regulations would be further relaxed and the whole financial sector reviewed. Greater effort would be applied to initiatives already underway in the public sector, including corporate and strategic planning, performance-based remuneration, performance-based contract employment for senior officials, improved financial systems and management, more effective budgeting, and increased devolution of financial and human resource management responsibility (Ministry of Finance and Ministry of National Planning 1997a; 1997b).

Although not as speedy and thoroughgoing as some would have liked, the progressive implementation of these reforms in the course of 1997 showed that the state was now more serious about its reform program. By late 1997 the Public Enterprise Act had been passed; the Government Shipyard was privatised and the Fiji Broadcasting Commission corporatised; the process of corporatising the Civil Aviation Authority of Fiji was well underway; further steps had been taken to sell 49 per cent of the Government's share of the national carrier, Air Pacific; the Capital Market Development Authority had been established; some foreign exchange controls relaxed; and significant progress had been made on public sector reform (Ministry of Finance and Ministry of National Planning 1997b; Fiji Times, 23 September and 7 October 1997). In the area of industrial relations, the Health and Safety at Work Act of 1996 was passed and, significantly, the Tripartite Forum, which brings together employers, employees and government representatives, was reconvened for the first time in two years (Fiji Times, 26 September and 7 October 1997). There was also a proposal to merge the Departments of Inland Revenue and Customs 
into a single 'revenue authority' (Fiji Times, 3 October 1997). Presented as a means of streamlining revenue collection, the proposal was also seen, however, as partly a response to the release the previous June of a report on an investigation into corruption in the Customs Department (Parliament of Fiji 1997b).

Reporting on this progress in November 1997, Jim Ah Koy, the new Finance Minister and one of Fiji's leading businessmen, announced yet more reforms, including further streamlining of investment approval procedures, greater liberalisation of foreign exchange controls, financial market reforms and various measures to achieve a 'large reduction' in the budget deficit, which in 1997 stood at 9.2 per cent of GDP. To 'speed up the public enterprise reform process', which was 'now very high on the Government's agenda', over F\$10 million was allocated to the Public Enterprise Unit over the next two years-an enormous increase over the $\mathrm{F} \$ 0.5$ million allocated one year earlier. In the area of public sector reform, some earlier initiatives such as employment contracts for Departmental Heads had not yet been implemented; but Ah Koy reaffirmed the government's commitment to push ahead with the reform program.

Reactions to the 1998 budget were mixed. Some saw it as an electoral sweetener; for others it did not go far enough and the government's softer position on deregulation was especially worrying. Just four months earlier a five-member panel drawn from the private sector had tabled its report on deregulation and had strongly argued for more wide-ranging reforms (Parliament of Fiji 1997a). But the various criticisms notwithstanding, it was clear that the government was committed to pressing ahead with its expanded reform program. That it was now being driven increasingly by global pressures was made clear by Ah Koy: 'our survival rests on how well we adjust to these daunting challenges. We cannot run away from these developments and isolate ourselves from the rest of the world' (Ministry of Finance and Ministry of National Planning 1997a:27). By then the deepening Asian crisis was increasingly taking its toll on the Fiji economy and further evidence that state policy was indeed being shaped by the logic of globalisation came in January 1998 when the Fiji dollar was devalued by 20 per cent.

With that the state's ability to resolve the Fijian question became even more limited. As it was, the nationalist agenda had already been severely compromised by the growing pace and expanded scope of 
the economic reforms, and the 1998 budget contained nothing to suggest an about-turn. As was the case with the budget address in the previous year, the 1997 address made no mention of indigenous Fijian interests and Josefata Kamikamica, leader of the Fijian Association Party (FAP), was quick to point this out. Section 44 of the 1997 Constitution, he reminded the government, explicitly required parliament to make provision for programs designed to help those that were disadvantaged. The 1998 budget, he complained, contained no specific program for this purpose. More specifically, the Fijian Affairs Ministry had not been provided with resources to develop an effective program and indigenous Fijian participation in business had not been adequately addressed (Pacnews, 10 November 1997). Kamikamica was, in effect, charging the government with doing a great deal less than before to resolve the Fijian question.

In the second half of the 1990s, then, the state increasingly distanced itself from its earlier nationalist agenda. In the first half of decade the contradictions between the needs of that agenda and those of economic liberalisation intensified and, pushed along by growing external pressures, the state shifted increasingly towards the latter. Driven now by global imperatives, it pressed ahead on the reform path and in so doing further limited its capacity to deliver on the Fijian question. The change of tack alienated the very political support on which the government depended for its survival. What, then, of the future?

\section{The Fijian question and Fiji's prospects}

The new constitution makes power-sharing mandatory and for some time after its enactment in July 1997 the general expectation was that the most likely outcome of the next general elections would be a coalition government of the two major political parties, the SVT and the NFP. Two factors, however, made this rather less certain. One was the growing political fragmentation amongst indigenous Fijians, as evidenced by the increase in the number of indigenous Fijian political parties; the other was the electoral coalition between the FLP, the indigenous Fijian FAP, and the Party of National Unity (PANU).

At the party level, one of the earliest signs of cracks within the indigenous Fijian community came in 1991. Less than one year after the promulgation of the racist and undemocratic constitution of 1990, Apisai Tora, then a Cabinet Minister, joined the recently-formed, 
western-based, multiracial All National Congress (ANC). As a westerner, he was concerned about eastern chiefly dominance, and believed that 'it [was] time western Fijians challenged the convention that eastern Fijians [were] the country's naturally-born leaders' (Sutherland 1992:203). He criticised the formation of the SVT and was promptly sacked. Over the next eight months intra-indigenous Fijian tensions intensified and by February 1992 there were no less than six indigenous Fijian political parties opposed to the SVT. Their small size and lack of resources, however, made them no match for the SVT and it easily won the general elections later that year. But a major split within the SVT beckoned. Disgruntled party members engineered the defeat of the 1994 budget and broke away to form the FAP. But it too could not match the resources of the SVT and in the snap elections held in 1995 won only five seats compared to the SVT's thirty-one.

By then, as shown above, the tide was turning against the indigenous Fijian nationalist agenda and later in 1995 the review of the 1990 Constitution got underway. In the course of the review, nationalist sentiment again came to the fore, including from within the SVT, and continued well after the Constitutional Review Commission presented its report in September 1996. With the adoption of a new, more democratic constitution in July 1997, however, the nationalist cause was dealt a severe blow. But the extremists would not give up easily and their cause was bolstered in the following October when Kavekini Navuso, a former member of the FLP and trade union leader, won a by-election under the banner of the recently-formed and Nationalist Vanua Takolavo Party. His objective, he announced, was to change the new constitution that had overturned indigenous Fijian political dominance and in his maiden speech in November he attacked the SVT government for selling out on indigenous Fijian rights (Pacnews, 25 November 1997).

In the same month, disgruntled members of the recently-formed Viti Levu Multiracial Democratic Dynamic Party broke away to form the Viti Levu, Kubuna, Burebasaga Multiracial Democratic Party. Headed by two chiefs, one from Ra and the other from Rewa, the party's main concern was to ensure an equal distribution of wealth between indigenous Fijians, especially those they saw as having been 'forgotten by the SVT and FAP' (Pacnews, 13 November 1997). By this time the SVT and the FAP had formed a coalition but negotiations for a merger were floundering and an FAP spokesman predicted that 
coalition with SVT would be over by Christmas. The main reason for this was the lack of consultation by the SVT, especially over the new constitution (Pacnews, 29 November 1997). In December the parliamentary coalition between the two parties collapsed and the FAP began to discuss with the FLP the possibility of jointly contesting upcoming elections (Pacnews, 31 December 1997).

By early 1998 rumours were circulating that an indigenous Fijian movement known as Cadra Mai, which means to rise up, was planning to topple the government and in February Prime Minister Rabuka challenged its members to come out into the open. He said he knew who they were and described them as a group of clergymen and senior military and police officers that had supported him in the coups of 1987 (Pacnews, 16 February 1998). The group was opposed to the new constitution and the government's moves to deal with the issue of native land leases through a Joint Parliamentary Select Committee (Pacnews, 18 February 1998). A few days after Rabuka's statement the head of the Methodist Church distanced the church from 'moves by some senior clergy to form a political party to rival the SVT' (Pacnews, 20 February 1998). Soon afterwards a new indigenous Fijian party, the Soqosoqo Vakakarisito Party (SVP) or Fijian Christian Party, was formed. Its leader, the Reverend Manasa Lasaro, was an extremist nationalist who had figured prominently in the events of 1987. There were thus in early 1998 five indigenous Fijian parties opposed to the SVT.

However, yet another indigenous Fijian party was in the offing. At a meeting in March 1998 the Ba Provincial Council unanimously agreed to form the PANU. Launched by no less a figure than the High Chief of $\mathrm{Ba}$, the Party appointed Apisai Tora as its general secretary. The PANU was the latest political expression of the longstanding regional cleavage between eastern and western indigenous Fijians. As a senior party official, echoing Tora's earlier expression of western indigenous Fijian resentment of eastern indigenous Fijian political dominance, put it, 'although [Ba] province controls 60 per cent of the country's resources, it does not have much say in the political arena' (Pacnews, 15 January 1998).

The threat from the new indigenous Fijian political parties was not lost on the SVT. Prime Minister Rabuka claimed that this was simply an indication of indigenous Fijians becoming more aware of politics (Pacnews, 2 April 1998). The uncomfortable reality, however, was that by the time the 1999 general elections took place the SVT was opposed 
by a number of rival indigenous Fijian parties, albeit with varying degrees of credibility. The threat to the SVT became even more real when an electoral coalition between the FAP, PANU and FLP was announced. In August 1998 the attractiveness of this coalition as an alternative to one between the SVT and the NFP was boosted by the election of Adi Kuini Bavadra to the leadership of the FAP following the death of Kamikamica earlier that month. Previously the wife of the late Dr Timoci Bavadra, former leader of the FLP and Prime Minister in the FLP-NFP Coalition government that was overthrown in 1987, Adi Kuini was a western chief but also had close family connections to the eastern chiefly establishment. Sharp, articulate and finely attuned to traditional indigenous Fijian politics, she also made a mark within the Great Council of Chiefs. Moreover, in September 1998, 27 per cent of people surveyed in a public opinion poll ranked her second as preferred Prime Minister, just one percentage point behind Prime Minister Rabuka (Pacific Islands Report, 28 September 1998). Advantages such as these no doubt figured prominently both in her election to the leadership of the FAP as well as in the eventual success of the FLP/FAP/PANU coalition in the 1999 general elections.

\section{Conclusion}

In the latter half of 1998, then, the evidence was becoming increasingly clear that SVT rule was unlikely to continue. The new electoral system could not guarantee indigenous Fijian political dominance, increasing indigenous Fijian disaffection had thrown up some credible indigenous Fijian rivals, and the new constitution required power sharing between electorally successful political parties. In this light, the outcome of the 1999 general elections is perhaps not as surprising as some have thought it to be.

However, the new government still faces the thorny Fijian question, a question that the SVT was unable to resolve. The highly sensitive matter of native land leases has not been settled and the stand-off between the government and landowners over compensation for land taken over for the hydroelectric power station in Monasavu will undoubtedly have long term effects. In the area of education, indigenous Fijian underperformance continues to be a problem. As recently as January 1998 poor indigenous Fijian performance in external examinations caused the government to 
commission yet another an investigation (Pacnews, 15 January 1998). On the economic front, ten years since its formulation, the grand design for greater indigenous Fijian control of the economy remains largely that-although, it is true, a small minority has prospered.

In the elections the failure of the indigenous Fijian-dominated postcoup state to resolve the Fijian question figured prominently. How the new government deals with it will be crucial for the country's prospects for economic growth and political stability. The danger is that for some indigenous Fijians there remains unfinished business. Against this stands the hope is that the greater democratic space that now prevails in Fiji will allow more sensitive and effective management of the problematics of reform and the Fijian question. 
This text is taken from Confronting Fiji Futures, edited by A. Haroon Akram-Lodhi, published 2016 by ANU eView, The Australian National University, Canberra, Australia. 